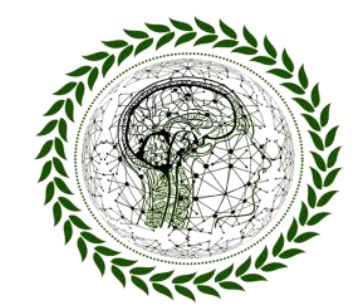

PhI Scientific Review

ISSN 2676 - 0444

Submetido em: 19/10/2021 | Aceito em: 01/11/2021 | Publicado em: 04/11/2021 | Artigo

\title{
UMA VISÃO CRÍTICA DOS CONTOS DE FADAS DOS GRIMM
}

Jefferson Silva Costa

\begin{abstract}
RESUMO
Os contos de fadas têm sido vistos, ao longo dos anos, sobretudo como lúdico, místico e mágico como que querendo empanar o outro lado da realidade como mensagem voltada para o "mundo dos adultos". Com base em leituras dos contos dos Irmãos Grimm, pretendese desmistificá-los com o intuito de demonstrar uma visão crítica da sociedade e da cultura que gerou os contos de fadas. A principal técnica a ser adotada será a da análise das características dos padrões literários da época dos referidos autores nos contos. Para tanto serão trabalhados os aspectos históricos, literários, culturais e sociais. Com esta pesquisa tem-se a pretensão de um maior aproveitamento crítico para a realidade do adulto, mostrando que infantilizar os contos de fadas pode não ser uma visão real do cidadão capaz de um pensamento crítico e abrangente dos contos.
\end{abstract}

PALAVRAS-CHAVE: Contos. Crítico. Adulto.

\begin{abstract}
The fairy tale has been seen, through the years, as playful, mistic and magic like trying to hide the other side of reality as a message made to the world of adults. Based in Grimm's brotrers fairy tale readings, pretend demystify them to demonstrate a critical vision of society and culture that started fairy tale. The main technique to be adopted will be the analysis of the characteristics of literary standards at that time of these related authors in the tales. In these tales it will be worked the historical, literary, cultural and social aspects. By this research pretend to make a better critical exploitation to the adults reality, to show them that make infantile the fairy tale can not be a real vision of capable citizen of a critical and including thought of tale.
\end{abstract}

KEYWORDS: Tale. Critical. Adults.

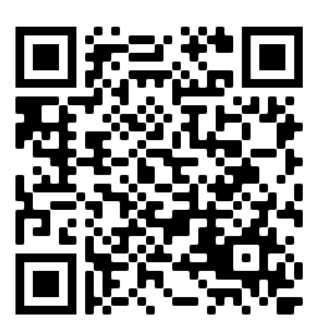

V. 01, No 06, novembro de 2021

Todos os direitos reservados@ 


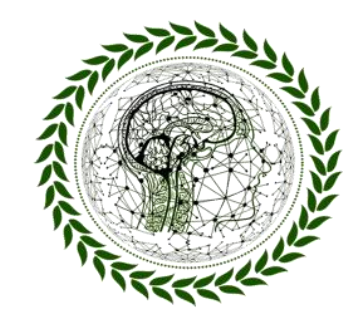

PhI Scientific Review

ISSN 2676 - 1444

\section{INTRODUÇÃO}

A necessidade de comunicar-se fez do homem um contador de histórias, descrevendo nestas, fatos e momentos da vida e de como interagiam em sociedade, enfatizando-as, para que houvesse maior valorização do que estava acontecendo.

Durante os séculos medievais, a sociedade era separada em três eixos bem definidos: clero, nobreza e servo; O clero era formado por pessoas nobres, por causa dos altos custos para os estudos. Os nobres não viravam servos nem se estivessem em decadência financeira. E o servo nascia servo e continuava assim para o resto da sua vida, sua única condição era trabalhar todos os dias, submetido aos seus senhores por diversos laços de servidão.

Nesse contexto, surgiram os contos de fadas, uma manifestação folclórica originada da cultura celta, que tem como características um idealismo extremo e um mundo de magias e de maravilhas. Utilizaram-se da imaginação dos camponeses, trabalhadores analfabetos, que em suas reuniões sociais, nas salas de fiar, contavam histórias que diziam como era o mundo e ofereciam estratégias para enfrentá-los.

Essas histórias camponesas eram narrativas complexas que fundidas com a herança céltica descreviam heróis, heroínas e seres imaginários, dotados de poderes sobrenaturais ligados ao mistério do além-vida. Essas estranhas fantasias e encantamentos visavam à realização interior do homem medieval. Todos esses fatos caracterizam as novelas de cavalaria do ciclo arturiano, novelas estas, das quais são encontradas as primeiras referências às fadas como personagens responsáveis pelo destino bom ou mau dos protagonistas e, representam forças psíquicas ou metafísicas.

As inspirações para as histórias contadas pelos camponeses derivam do cotidiano destes, que apresentavam um contraste entre a segurança da casa e da aldeia com os perigos da estrada e da floresta. Assim sendo, a crueldade, malícia e erotismo faziam parte do roteiro que culminava em finais infelizes. Não eram destinadas ao público infantil, pois não havia distinção entre infância e idade adulta, pois as crianças se vestiam e trabalhavam como os adultos. Tendo essas histórias o intuito de educar e unir a comunidade.

V. 01, $\mathrm{N}^{\mathrm{o}}$ 06, novembro de 2021

Todos os direitos reservados $\odot$ http://www.revistaphd.periodikos.com.br 


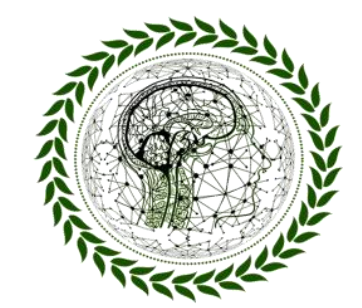

PhI Scientific Review

ISSN 2676 - 0444

Ribeiro (2005, p.54) relata que:

[...] Chapeuzinho Vermelho não usava um chapeuzinho vermelho. E o lobo matava a vovó, enchia uma jarra com o seu sangue e fatiava sua carne. Quando a menina chegava, ele, já travestido, mandava que ela se servisse do vinho e da carne. Depois, pedia à menina para se deitar nua com ele. [...] E a história terminava com o lobo devorando a garota. Sem caçador para salvála, sem final feliz e sem medo de mexer com tabus.

[...] Assim eram as versões primitivas de Cinderela. Em uma das histórias, a moça vira empregada para fugir do assedio sexual do pai. Em outra, a madrasta, tentando matar a enteada, joga uma de suas filhas na fogueira. [...] o pai de Cinderela casa-se com uma mulher que a trata mal, quando ela queria que ele se casasse com a governanta. Cinderela então, assassina a madrasta.

[...] os detalhes de A Bela Adormecida arrepiam. O príncipe encantado já é casado e viola a princesa durante o sono. Ela tem dois filhos com ele, ainda dormindo, e é despertada não por um beijo, mas pela mordida de um dos filhos enquanto os amamenta. A sogra do príncipe descobre tudo e tenta matar e comer a princesa e as crianças bastardas.

Gradualmente esse tipo de narrativa foi simplificado, introduzindo-se nos domínios da literatura infantil. A partir do século XIX, com a Revolução Industrial e Francesa, alguns valores mudaram e fizeram desta fase decisiva para a humanidade, pois trouxe a consolidação da sociedade burguesa, estruturação familiar e aceitação da criança como um ser que precisava de cuidados específicos para sua formação humanística, cívica, espiritual, ética e intelectual.

Os escritores alemães Jacob Grimm (1785-1863) e Wilhelm Grimm (1786-1859), influenciados pelo pensamento filosófico romântico da época que tinha como tema central "a liberdade do indivíduo em relação ao poder dominante da aristocracia" - representado pelo poeta Goethe e pelo filósofo educador Schiller, coletou na cultura popular e na tradição oral a inspiração para os seus contos de fadas. Sendo filólogos, seu interesse inicial era 


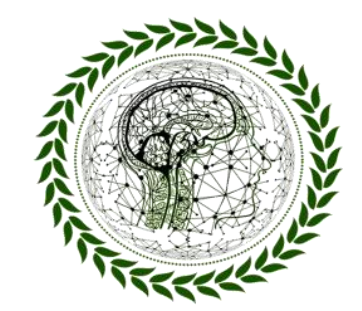

PhI Scientific Review

ISSN 2676 - 1444

coletar tais contos para estudar a língua alemã e registrar seu folclore, de modo a recuperar a realidade histórica do país.

Esses contos jamais pretendiam ser contos infantis, devido ao seu objetivo inicial. Mas foi bem aceito pelas crianças e famílias burguesas e aos poucos foi transformado em leitura para as crianças dormirem. Em sua primeira edição, os textos foram publicados separadamente contendo ainda finais cruéis. No entanto, alguns pedagogos do Iluminismo denegriram a imagem dos contos de fadas, defendendo que se tratava de histórias contadas por mulheres ignorantes e desprovidas de intelectos.

Devido à influência cristã consolidada na época, e diante da polêmica levantada pelos intelectuais, os irmãos Grimm em sua segunda edição, se vêm obrigados a retirar os episódios de violência ou maldade, principalmente daqueles em que eram praticados contra crianças. Com essa edição, os contos de fadas se disseminaram e designaram o termo Literatura Infantil.

Bem como nas histórias de Perrault - escritor francês do século XVII que também coletou da tradição popular as histórias para os seus contos - os episódios e personagens possuem semelhanças com os enredos dos Grimm, evidenciando assim, um fundo comum de fontes folclóricas. Tomemos, por exemplo, a história do Chapeuzinho Vermelho que no enredo dos Grimm tem o seu final idealizado, feliz e satisfatório com Chapeuzinho sendo salva pelo bravo caçador. Já na narrativa do francês o final apresenta-se desastroso para a menina que sofre fatalmente pelo ato impensado e desobediente. Com esse desfecho Perrault sublinha uma idéia de realidade fatal e cruel.

O conto de "Chapeuzinho Vermelho" de Perrault (2004, pág. 338):

[...] Toc, toc, toc. "Quem está aí?" Ouvindo a voz grossa do lobo, Chapeuzinho Vermelho primeiro teve medo, mas, pensando que a avó estava gripada, respondeu: “É a sua neta, Chapeuzinho Vermelho. Estou trazendo bolinho e potinho de manteiga que a minha mãe mandou." O lobo gritou de volta, adoçando um pouco a voz: "Puxe a lingüeta e o ferrolho se 


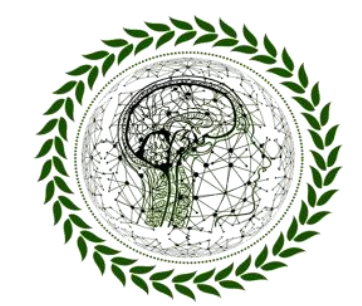

\section{PhI Scientific Review \\ ISSN 2676 - 0444}

abrirá." Chapeuzinho puxou a lingüeta e a porta se abriu. O lobo vendo-a entrar, disse-lhe, escondendo-se na cama debaixo das cobertas: "Ponha o bolo e potinho de manteiga em cima da arca, e venha se deitar comigo." Chapeuzinho Vermelho tirou a roupa e foi se enfiar na cama, onde ficou muito espantada ao ver a figura da avó na camisola. Disse a ela: “Minha avó, que braços grandes você tem!" "É para abraçar você melhor, minha neta." "Minha avó, que pernas grandes você tem!" "É para correr melhor, minha filha." "Minha avó, que orelhas grandes você tem!" "É para te escutar melhor, minha filha." "minha avó, que olhos grandes você tem!" “è para enxergar você melhor, minha filha." "Minha avó, que dentes grandes a senhora tem!" "É para comer você." E dizendo estas palavras, o lobo malvado se jogou em cima de Chapeuzinho Vermelho e a comeu.

O conto dos Grimm (2005, pág. 286) temos:

[...] Chapeuzinho Vermelho andou colhendo flores por todo lado até encher os braços e então se lembrou da avó. Quando chegou à casa dela, ficou admirada de encontrar a porta aberta, e assim que entrou o quarto e tudo o mais the pareceu muito estranho.

Ela se sentiu apreensiva, mas não sabia a razão. "Em geral gosto tanto de ver vovó", pensou. E então disse:

- Bom-dia, vovó. - Mas não recebeu resposta.

Foi então até cama e abriu o cortinado. A avó estava deitada, mas puxara a touca para cobrir o rosto e tinha uma aparência estranha.

[...] - Mas, vovó, que dentes grandes a senhora tem.

- É para comê-la melhor, minha querida.

Mal acabara de dizer isso, o lobo pulou da cama e devorou a pobre Chapeuzinho Vermelho. Quando se deu por satisfeito, voltou para cama e logo começou a roncar alto.

Um caçador passou pela casa e pensou: "Como a velha está roncando alto. Preciso ver se está acontecendo alguma coisa com ela." 


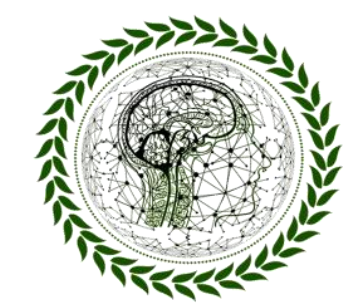

\section{PhI Scientific Review \\ ISSN 2676 - 0444}

Ele entrou na casa, aproximou-se da cama e encontrou o lobo ferrado no sono.

- E não é que o encontro aqui, seu velho pecador! - exclamou. - Faz bastante tempo que venho procurando você.

E ergueu a espingarda para atirar, mas ocorreu-lhe que talvez o lobo tivesse comido a velha e que talvez ainda pudesse salva-la. O caçador apanhou uma faca e começou a abrir a barriga do animal. No primeiro corte viu o pequeno capuz vermelho e, com mais alguns golpes, a menininha pulou para fora e exclamou:

- Ah, que medo eu tive, estava tão escuro dentro do lobo! - Em seguida a velha avó saiu, viva, mas mal conseguia respirar.

[...] Todos ficaram bem satisfeitos. O caçador esfolou o lobo e levou a pele para casa. A avó comeu o bolo e bebeu o vinho que sua neta trouxera, e logo se sentiu mais forte. Chapeuzinho Vermelho pensou: “Quando minha mãe proibir, nunca mais vou sair passeando pela floresta enquanto eu viver."

Charles Perrault mantém em seus contos traços classicistas, sendo mais racionais (razão vem antes da emoção) com uma literatura direta e simples, já os contos dos irmãos Grimm trazem uma predominância romântica, com uma literatura mais fantasiosa e subjetiva sendo acrescentadas a eles um final feliz. É justamente nesses textos dos alemães, que se encontram as características literárias românticas, tais como escapismo, culto ao fantástico, subjetivismo, idealização da mulher, natureza como tema poético, culto aos ideais da Idade Média e egocentrismo.

Todas essas características são encontradas no âmbito de uma cultura européia do século XIX - Família, Religião e Estado - com pretensão de organização social possuindo uma fácil identificação com qualquer realidade. Porém, a presença do místico, maravilhoso e fantástico não deve ser comparada com lúdico.

Eliade (2004, p.173) diz que:

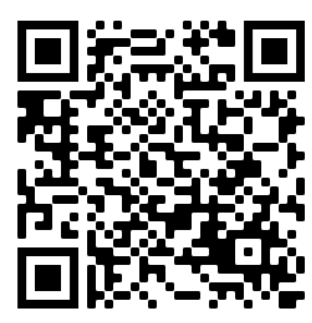

V. 01, No 06, novembro de 2021

Todos os direitos reservados $\odot$ http://www.revistaphd.periodikos.com.br 


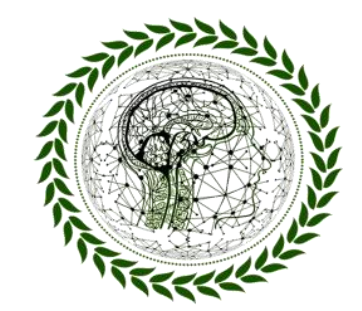

\section{PhI Scientific Review \\ ISSN 2676 - 0444}

[...] Embora, no Ocidente, o conto maravilhoso se tenha convertido há muito tempo em literatura de diversão (para as crianças e os camponeses) ou de evasão (para os habitantes da cidade), ele ainda apresenta a estrutura de uma aventura infinitamente séria e responsável, pois se reduz, em suma, a um enredo iniciatório: nele reencontramos sempre as provas iniciatórias (lutas contra o monstro, obstáculos aparentemente insuperáveis, enigmas a serem solucionados, tarefas impossíveis, etc.), [...] É verdade, como justamente salientou Jan de Vries que o conto sempre se conclui com um Happy end. Mas, seu conteúdo propriamente dito refere-se a uma realidade terrivelmente séria: a iniciação, ou seja, a passagem, através de uma morte e ressurreição simbólica, da ignorância e da imaturidade para a idade espiritual do adulto.

Através dos contos de fadas, são oferecidos os modelos de "comportamento maniqueísta", que devem ser adotados como virtudes - a atitude certa deve ser copiada e a errada evitada, visto que, essa é tida como defeito humano - tendo então, como principal doutrina a formação de valores. Existem inúmeros contos que abordam tais estruturas, mas serão trabalhados em específicos os contos: Branca de Neve, João e Maria, A Gata Borralheira, Rapunzel, A Bela Adormecida, por conterem neles o elemento "Fada", característica principal deste tipo de narrativa, sendo todos estes, adaptações dos Irmãos Grimm às tradições orais da Europa contendo todos, uma eloqüência infantil, ludibriando assim, as imposições sociais.

\section{ANÁLISE DOS CONTOS:}

"Desde tempos imemoriais, alguns contos têm sido usados para fazer proselitismo de certas maneiras de ser, agir e pensar." (ESTÉS, Conto dos Irmãos Grimm-2005 p. 14). Usando como subsídio o pensamento da Dra. Clarissa Pinkola Estés - Doutora em Estudos Multiculturais e Psicologia Clínica - analisa-se os contos, como sendo textos que não só tinham o intuito de 


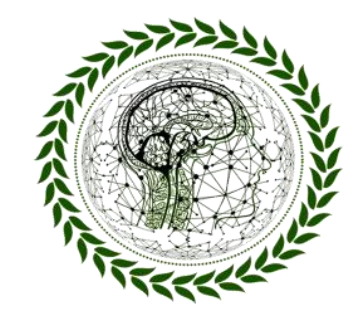

\section{PhI Scientific Review \\ ISSN 2676 - 0444}

educar, mas também entreter e agradar a classe dominante - a burguesia - com enredos idealizados e convenientes. Assim como fizeram os camponeses, Jacob e Wilhelm Grimm adaptaram as histórias com um fio condutor a sua realidade, incluindo nelas, comentários simbólicos sobre os costumes da sociedade que estavam inseridos, utilizando-se das características dum movimento artístico e cultural - O Romantismo.

\subsection{A mulher}

Por serem narrativas fantásticas e possuírem elementos encantados, principalmente "As Fadas" como tema central, essa análise partirá desse elemento e das intervenções que eles fazem em todos os textos abordados. Mesmo esses, apresentando como personagens principais, adolescentes femininas que, após viverem terríveis problemas, criados por seres de péssimo caráter - as bruxas, as madrastas, as irmãs malvadas, etc. - conseguem solucionar seus conflitos, auxiliadas pela entidade fada, que as ajudam a vencer obstáculos, encarar vilões, superar dramas e suspenses.

ESTÉS (2005, P.49), sobre "A Bela Adormecida":

[...] Quando onze das fadas já haviam falado, a décima terceira apareceu inesperadamente. Queria se vingar por não ter sido convidada. E sem cumprimentar ninguém e nem mesmo olhar para os convidados disse em alto e bom som:

- A princesa vai se espetar em uma roca em seu décimo quinto ano e cairá morta - e sem mais dizer ela se retirou do salão.

Todos ficaram horrorizados, mas a décima segunda fada, que ainda não formulará o seu desejo, adiantou-se. Não poderia cancelar a maldição, apenas abrandá-la, então disse:

- Sua filha não morrera, cairá em um sono profundo que durará cem anos. 


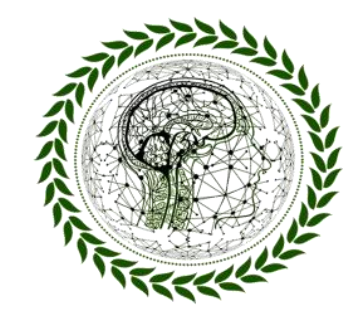

\section{PhI Scientific Review \\ ISSN 2676 - 0444}

O texto citado apresenta o conflito entre os dois tipos de fadas: a boa e a má, mostrando como elas podem intervir na vida dos mortais e decidirem o seu futuro. A fada boa, depuradas pelo cristianismo, aparecem nessas histórias com uma única e bem definida forma: são mulheres brancas, de feições finas, cabelos loiros. Vestem vestidos belíssimos, bordados de ouro e prata. Na cabeça usam chapéus em forma de cone, muito semelhantes aos da bruxa, acentuando naturalmente, o parentesco entre elas. Vem atuando sempre como defensora do bom propósito e da conduta moral. Já a bruxa ou a madrasta, é conceituada como uma entidade maléfica com origens nas crenças pagãs, e na maioria dos casos, é representada como mulheres velhas, feias, com nariz pontiagudos com uma verruga na ponta, vestem roupas surradas e escuras, agindo sempre contra a bondade e a pureza das jovens princesas e crianças.

As fadas possuem a caracterização do fantástico e do místico e utilizam-se sempre da magia tanto para o bem como para o mal. Os fragmentos retirados dos contos, Branca de Neve e da Bela Adormecida, exemplificam essa conduta.

ESTÉS (Conto dos Irmãos Grimm-2005 p.33-34) - Branca de Neve:

[...] Um ano depois o rei casou-se outra vez. Era uma mulher bonita, mas orgulhosa e dominadora, que não conseguia suportar que alguém superasse sua beleza. Possuía um espelho mágico e quando se postava diante dele costumava indagar[...]

- Espelho, espelho meu, há no mundo alguém mais belo do que eu?

E o espelho respondeu como de costume:

- Sois a mais bela aqui, reafirmo, mas Branca de Neve, no alto da colina, fez com os anões moradia e ainda é mil vezes mais bela.

[...] Pensou então: "Preciso imaginar alguma coisa que dê um fim a ela". Recorrendo à feitiçaria, em que era perita, preparou um pente envenenado. [...] E em seguida entrou em um aposento secreto, a que somente ela tinha acesso, e preparou uma maça envenenada. [...].

V. 01, No 06 , novembro de 2021

Todos os direitos reservados ( http://www.revistaphd.periodikos.com.br 


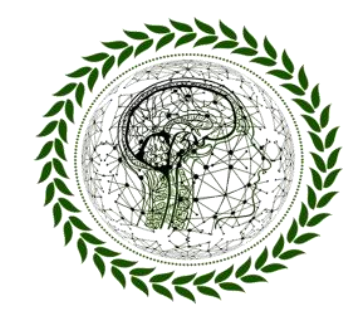

PhI Scientific Review

ISSN 2676 - 1444

ESTÉS (Conto dos Irmãos Grimm-2005 p.49) - Bela Adormecida:

O banquete foi preparado com grande esplendor e quando terminou todas as fadas deram à criança um presente mágico. Um deu-lhe virtude, outra, beleza, uma terceira, riqueza e assim por diante, concedendo-lhe tudo que poderia desejar no mundo.

Pode-se atribuir toda essa valorização feminina, exemplificado no elemento fada, ao povo celta que acreditava ser a mulher o ponto de equilíbrio do mundo, e estas eram quem possuíam todo o conhecimento da magia - "bruxas medievais".

A maioria das mulheres nos contos apresentava a fragilidade como característica, sendo poucas as que com o sofrimento transformam-se em mulheres mais decididas. Estas também podem ser abordadas na figura infantil mais não se obtêm do mesmo sentimento da adulta. No caso do conto João e Maria, há uma mudança de conduta, mesmo sendo Maria uma garotinha sensível, é ela quem atira a bruxa no forno fazendo-a morrer queimada: “A bruxa se aproximou e meteu a cabeça no forno. Mas Maria deu-lhe um empurrão que a arremessou para dentro, em seguida bateu a porta e passou a tranca no forno." (ESTÉS, Conto dos Irmãos Grimm-2005 p.219).

Em todo o caso, não existe nas histórias em que não se atribua à mulher tanto o bem como o mal, fazendo delas, um esquema seqüencial do conto. Já que estas iniciam, fazem o conflito, intervêm, vencem e são derrotadas. Essa derrota cabe sempre as fadas más que instigadas por um sentimento individualista não aceitam especificidades atribuída às mocinhas, não poupando esforços realizam atos maléficos para destruí-las. 


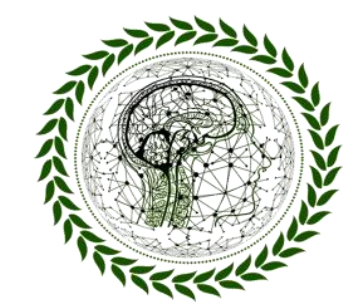

PhI Scientific Review

ISSN 2676 - 1444

\section{$1.1 \mathrm{O}$ bem e o mal}

Dentro das narrativas dos contos, fica bem claro a distinção entre personagens do bem e do mal, tanto na postura quanto no subseqüente destino, feliz para o bonzinho e cruel para o malvado.

ESTÉS (2005, P.61), sobre “A Gata Borralheira":

“Depois que lavou as mãos e o rosto, ela foi à sala e fez uma reverência ao príncipe que lhe entregou o sapato dourado.

Ela se sentou em um banco, tirou os tamancos de madeira e calçou os sapatos que coube certinho em seu pé.

E quando se levantou o príncipe olhou bem o seu rosto, reconheceu a linda moça com quem dançara e exclamou:

- Está é a noiva certa!

A madrasta e suas filhas ficaram desoladas e brancas de tanta raiva; mas ele montou Borralheira em seu cavalo e partiu.

Ao passarem pela aveleira os pombos brancos cantaram [...]

E dizendo isso os dois desceram e posaram nos ombros de Borralheira, um no direito outro no esquerdo e ficaram empoleirados ali.

Na hora do casamento, as duas falsas irmãs apareceram para adular a Borralheira e participar de sua boa sorte. Quando o cortejo nupcial se dirigiu a igreja a mais velha se sentou a sua direita e a mais nova a sua esquerda, e os pombos furaram um olho de cada uma.

Mas, na saída da igreja, a mais velha ficou à esquerda e a mais nova à direita, e os pombos furaram o outro olho de cada uma. Assim a maldade e a falsidade delas foram punidas para o resto da vida com a cegueira.

Por trás dessa determinada postura é apresentada, atrelado a um viés, certo juízo de valores que coloca a postura ética como a solução para os males que podem aparecer, ou seja, o sujeito tido como correto, por mais que enfrente dificuldades será recompensado por um 


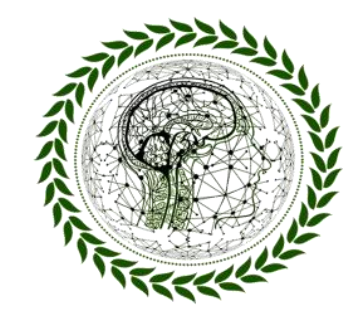

\section{PhI Scientific Review \\ ISSN 2676 - 0444}

destino justo e feliz. O mesmo não acontece com o sujeito de postura contraria - o personagem do mal - que acaba recebendo um destino cruel e muitas vezes fatal.

Com isso os contos têm como intensão disseminar os ideais cristãos em relação à bem e mal, ideais estes, que colocam o bem como vencedor, pois o mesmo representa a justiça divina. Já o mal é a representação da oposição às coisas boas e com isso fica diretamente ligado as forças obscuras, representadas nos contos por bruxas que usam a feitiçaria a serviço do mal e que evidentemente devem ser punidas para satisfazerem à sede de ética cristã tão defendida pelos românticos.

No conto, Rapunzel foi aprisionada pela bruxa Gotel - termo comum na Alemanha para uma madrinha, e caracteriza uma mãe super protetora - que por querer super protegêla, a aprisiona na torre para que ela não tivesse mais contato com outras pessoas, deixando-a solitária. Em contra partida, as bruxas ou elementos que possuam a mesma característica sofrem as consequências dos seus atos maldosos, "o feitiço vira contra o feiticeiro". As bruxas padecem sobre as terríveis punições, em grande maioria, estas repreensões são as mortes cruéis.

ESTÉS (2005, P.41), sobre “Branca de Neve":

\footnotetext{
“Então a malvada soltou uma praga e ficou tão horrivelmente assustada que não soube o que fazer. Contudo não descansou: sentiu-se obrigada a ir ver a jovem rainha. E quando entrou e reconheceu Branca de Neve, ficou paralisada de apreensão e terror. Mas o príncipe mandou esquentar sapatos de ferro ao fogo, apanha-los com pinça em brasa e coloca-los e dançar até cair morta."
}

\subsection{Idealização da realidade}

Dada a intenção romântica de criar uma realidade confortante, os contos dos Grimm apresentam enredos de uma realidade fantasiosa que de certa forma contribui para o preenchimento, no leitor, de um vazio encontrado em sua realidade não tão agradável. $\mathrm{O}$ 


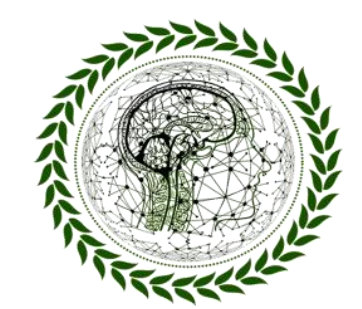

PhI Scientific Review

ISSN 2676 - 1444

mundo de fantasia dos contos acabava virando uma necessidade para anular a dor de viver a realidade. Esta não atenção à realidade acabava contribuindo para um enfraquecimento do pensamento crítico e um fortalecimento da alienação fato que muito agradava a elite burguesa que usaria tais contos para manter o indivíduo atrelado a uma realidade utópica e não atento ao mundo vivo ao seu redor.

ESTÉS (2005, P.51), sobre “A Bela Adormecida":

Acontece, porém, que os cem anos haviam terminado e chegara o dia em que a Bela Adormecida deveria despertar. Quando o príncipe se aproximou a cerca de ericas estava em flor, coberta de flores graúdas e belas que abriram caminho para ele voluntariamente e o deixaram passar sem lhe fazer mal, e em seguida tornaram a se fechar à sua passagem.

A sucessão de fatos e coincidências que levam o príncipe belo e valente a encontrar a princesa em certo tempo e lugar, deixa clara a conotação fantasiosa das ações do conto, pois as mesmas são destoantes dos fatos da realidade que não funcionam, tão harmoniosamente, para ajudar na concretização do amor.

ESTÉS (2005, P.263), sobre “Rapunzel”:

O príncipe ouviu uma voz que lhe pareceu muito conhecida e caminhou em sua direção. Rapunzel reconheceu-o imediatamente e desatou a chorar em seu ombro. Duas de suas lágrimas caíram nos olhos dele fazendo-os clarear imediatamente, e o príncipe voltou a ver como antes. Levou-a então para o seu reino onde foi recebido com alegria, e ele e Rapunzel viveram juntos uma vida longa e feliz.

V. 01, $\mathrm{N}^{\mathrm{0}}$ 06, novembro de 2021

Todos os direitos reservados $\odot$ http://www.revistaphd.periodikos.com.br 


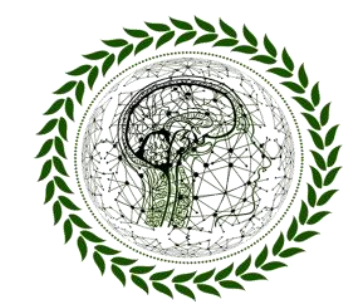

PhI Scientific Review

ISSN 2676 - 1444

\subsection{A natureza:}

Os camponeses do século XVI viviam em vilas, que para eles era um lugar seguro, no entanto tinham ao seu redor a floresta, que representava o desconhecido, fazendo com que houvesse todo um mistério aflorando suas imaginações.

Por ser a floresta o pivô de toda a assombração do fenômeno desconhecido, é neste local que aparece toda a fantasia do imaginário popular europeu: ursos falantes, lobo, bruxas e anões que habitam toda essa área fantástica causando certo confronto e choque aos personagens que entram em contato com esses elementos nem sempre ofensivos, tornandose assim, a natureza um pano de fundo nas histórias dos camponeses.

ESTÉS (2005, P.34), sobre "Branca de Neve":

A coitadinha ficou só na vasta floresta sem viva alma por perto e se sentiu tão amedrontada que não soube o que fazer. Começou então a correr, saltou por cima de pedras pontiagudas, atravessou os espinheiros, enquanto os animais passavam por ela sem lhe fazer mal. Correu o mais longe que seus pés puderam carregá-la, e quando começou a anoitecer viu uma casinha onde entrou para descansar. [...]

Logo que a noite acabara de cair chegaram os donos da casa. Eram sete anões que costumavam extrair minérios nas montanhas.

ESTÉS (2005, P.51), sobre “Bela Adormecida":

Ao redor do castelo nasceu uma cerca de eriças; ano a ano a cerca foi subindo sem parar até que finalmente cobriu tudo, fazendo o castelo desaparecer de vista [...].

Mas pelo reino correu uma lenda sobre uma bela adormecida filha do rei, cujo o nome era Érica, e de tempos em tempos acorriam príncipes que tentavam atravessar a cerca para entra no castelo. Descobriam que era 


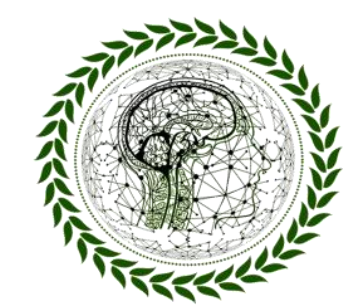

\section{PhI Scientific Review \\ ISSN 2676 - 0444}

impossível. Os espinhos os agarravam como se fossem mãos, e os príncipes sem conseguir se soltar acabavam sofrendo uma morte infeliz.

ESTÉS (2005, P.263), sobre “Rapunzel":

O príncipe ficou transtornado de pesar e em seu desespero pulou pela janela. Não morreu, mas seus olhos foram arrancados pelos espinhos dos arbustos em que caiu. Ele vagou às cegas pela floresta, se alimentando apenas de raízes e frutinhas.

O esboço teórico criado pelo Romantismo absorvia com facilidade a natureza como algo imaginário e utópico. Os irmãos Jacob e Wilhelm Grimm, sensíveis a essa facilidade e padrão romântico, com muita habilidade levaram isso para o conto, que já possuía desde sua criação, grande tendência à natureza como espaço narrativo, as suas descrições eram idealizadas, locais quase perfeitos que interagem com as personagens.

ESTÉS (2005, P. 220), sobre “João e Maria":

- Não tem caminho nem ponte e não podemos passar. Nos leve depressa nas costas, patinho que está aí a nadar!

O pato veio nadando a seu encontro, João montou em suas costas e disse à irmã para sentar em seu colo.

- Não - respondeu Maria -, ficará pesado demais para o pato; ele precisa levar um de cada vez.

A boa ave assim fez e, quando estavam na outra margem sãos e salvos, caminharam durante mais algum tempo. A floresta começou parecer familiar, e por fim avistaram ao longe a casa do pai. 


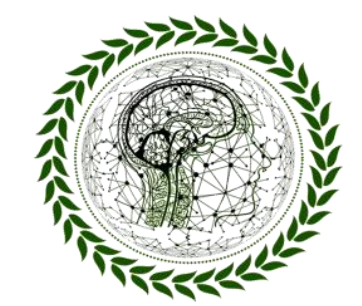

\section{PhD Scientific Review}

ISSN 2676 - (144

ESTÉS (2005, P. 56), sobre "A Gata Borralheira":

Muito bem, para as duas enteadas ele trouxe belas roupas, pérolas e jóias, e na volta para casa, ao passar por um arvoredo verdejante, roçou nele um raminho de aveleira que derrubou o seu chapéu. Então o homem partiu-o e o levou.

Quando chegou em casa deu às duas enteadas o que haviam pedido e à Borralheira deu o raminho de aveleira.

Borralheira agradeceu ao pai, foi ao túmulo da mãe e ali plantou o raminho; chorou tanto que suas lágrimas o regaram, e o raminho criou raízes e se tornou uma bela árvore.

Borralheira ia ao túmulo três vezes ao dia, chorava e rezava, e todas as vezes um passarinho branco vinha se empoleirar na árvore; quando ele formulava um desejo, o passarinho lhe atirava o que pedira.

Nas citações dos contos acima, percebe-se uma linguagem romântica e fantástica, com descrições que cultuam a natureza como algo primoroso, extraordinário e admirável que retoma e exemplifica as características românticas. "Era pleno inverno e os flocos de neve caiam do céu em plumas. Ora, uma rainha estava sentada a uma janela emoldurada de ébano e, enquanto costurava apreciava a neve cair." (ESTÉS, Conto dos Irmãos Grimm-2005 p. 33).

\section{CONCLUSÃO}

O ato de contar história é milenar e sempre existiu como uma ferramenta importante de transmitir conhecimento, padrões estilísticos além de formas de cultura e pensamento em uma época. $\mathrm{O}$ conto de fadas foi assim. Feito com a intenção de ensinar através de história ilustrativas, mirabolantes e maravilhosas o conto ganhou forma e força porque surgiu nele e com ele uma verdadeira vocação cultura, além de pedagógica. O conto em sua essência não 


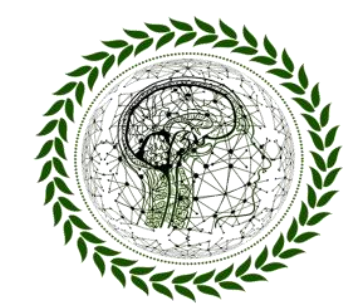

\section{PhI Scientific Review \\ ISSN 2676 - 0444}

foi feito para criança, foi feito sim para ensinar, passar conhecimentos e padrões culturais a adultos que seriam mais facilmente atingidos por bruxas, fadas, anões e outros estereótipos de uma sociedade. Estereótipos esses que impregnados de forma subjetivas são absolvidos com mais facilidade. Por causa dessa predestinação cultural o conto não ficou fixado no tempo e foi passando através dele com adaptações que o tornariam, de forma empanada, em Literatura Infantil. Entretanto o conto é mais que isso. O conto com suas ambigüidades e metáforas escondidas passa a ser um núcleo de ensinamentos, de conceitos, padrões de vida e de esperanças, além de desejos de épocas e fixação de estilos literários que, na mão de homens sensíveis, foram compilados e trazidos para a realidade da época em que viveram.

Em pleno século XVI, camponeses contavam histórias mirabolantes, drásticas e libidinosas sobre o desconhecido - a floresta - nela, toda fantasia e imaginação germinavam aos camponeses com noções perversas e diabólicas. Nesta época, a divisão entre criança e adulto não existia e as tristes histórias eram contadas não só como passatempo, mas também com o intuito de assustar os seres menores e fazer com que ele se afastasse da floresta não esquecendo do foco educativo em que essas histórias se baseavam, pois por trás de todo fantástico existe lições de morais que se baseavam em preceitos morais existentes na época.

Os contos de tradição oral foram se alastrando até que chamou a atenção de estudiosos da linguagem fazendo com que estes registrassem tais tradições.

Os Irmãos Grimm são um destes, buscaram registrar tais folclores para que houvesse uma valorização de sua cultura, essa coleta, a priori, foi feita exatamente como era contada pelos camponeses, havendo descriminação por parte da burguesia que estava em ascensão e já havia separado a idade adulta da criança, exigiu que os Grimm reformulasse suas escritas com bases na escola literária romântica, de modo que pudessem ser consideradas dignas de serem lidas pelo público infantil e, acima de tudo, responderem as intenções moralizantes de sua época.

Essa visão romântica e pueril acabou empanando toda uma linguagem cheia de simbologia educacional e acabou sendo banalizada por leitores que só conseguiam notar o que estava explícito, ou seja, narrativas voltadas para a criança.

V. 01, $\mathrm{N}^{\mathrm{o}}$ 06, novembro de 2021

Todos os direitos reservados $($ ) http://www.revistaphd.periodikos.com.br 


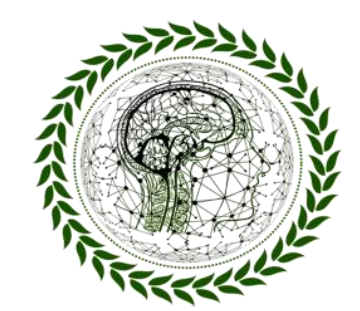

PhI Scientific Review

ISSN 2676 - 1444

Analisando melhor um conto de fada pode-se notar todo um desenvolvimento cultural - Estado, Religião e Família - que sobreviveu nos contos apesar das readaptações que eles sofreram. Quando foram compilados pelos Grimm, os contos de fadas não foram escritos direcionado ao público infantil.

Com esse artigo e os tópicos desenvolvidos no mesmo conclui-se que a infantilização e aparente inocência dos contos de fadas é uma ideia errônea, uma vez que tais contos atrelados aos seus enredos traziam uma carga política e filosófica muito grande abastecidos em uma fonte ideológica romântica

\section{Referências:}

BETTELHEIM, Bruno. A psicanálise dos contos de fadas. Rio de Janeiro: Paz e Terra, 1980.

COELHO, Nelly Novais. Panorama histórico da literatura infantil e juvenil. $4^{\mathrm{a}}$ ed. São Paulo: Ática, 1991.

. Os contos de fadas. São Paulo: Moderna, 2003.

CUNHA, Maria Antonieta Antunes. Literatura infantil: teoria e prática. $18^{\mathrm{a}}$ ed. São Paulo: Ática, 1999.

ELIADE, Mircea. Mito e realidade. $6^{\mathrm{a}}$ ed. São Paulo: Perspectiva, 2004.

ESTÈS, Dra. Clarissa Pinkola. Contos dos irmãos Grimm. Rio de Janeiro: Rocco, 2005.

PERRAULT, Charles. Contos de Perrault. $3^{\text {a }}$ ed. Belo Horizonte: Villa Rica, 1992. 


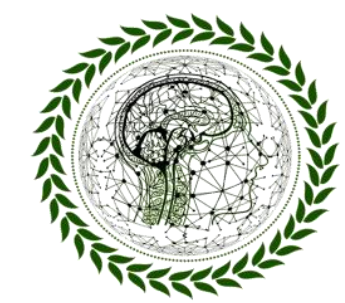

PhI Scientilic Review

ISSN 2676 - 1444

PROPP, Vladimir I. Morfologia do conto maravilhoso. Rio de Janeiro:Forense Universitária, 1983.

RIBEIRO, Flávia. Quem tem medo do lobo mau? Aventuras na História. São Paulo: Abril, 2005.

TODOROV, Tzevetan. Introdução à literatura fantástica. $2^{\mathrm{a}}$ ed. São Paulo: Perspectiva, 1992. WEBIOGRAFIAS

http://pt.wikipedia.org/wiki/Contos_de_fadas

http://pt.wikipedia.org/wiki/Contos_maravilhosos

http://www.educacional.com.br/projetos/ef1a4/contosdefadas/contos.html

http://www.graudez.com.br/litinf/

http://www.unicamp.br/iel/memoria/Ensaios/LiteraturaInfantil/Bibliografia.htm

http://www.proext.ufpe.br/cadernos/educacao/liter.htm

http://www.graudez.com.br/litinf/autores/grimm/grimm.htm

http://pt.wikipedia.org/wiki/Charles_Perrault

V. 01, No 06, novembro de 2021

Todos os direitos reservados@ http://www.revistaphd.periodikos.com.br 